\author{
حفظ خصوصيات كيفى انكور رقم "بيدانه قرمز"با استفاده از يوشش خوراكى \\ كايتوسان، اسانس آويشن و تركيب آنها

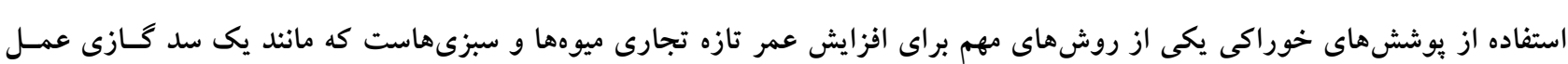

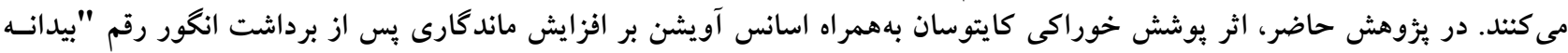

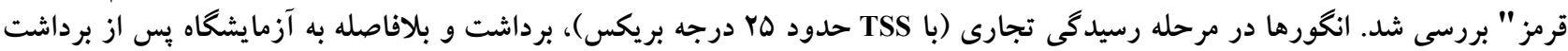

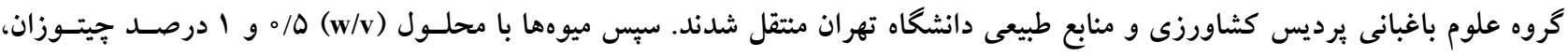

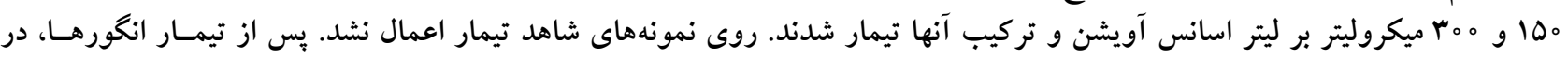

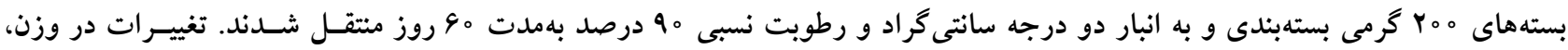

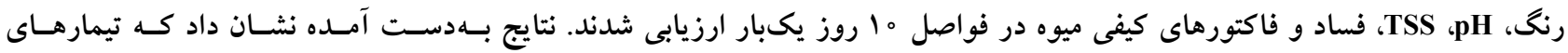

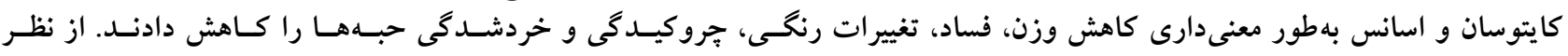

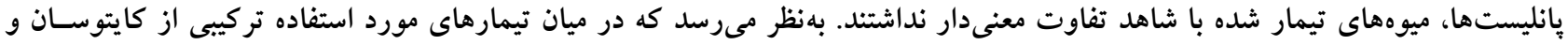

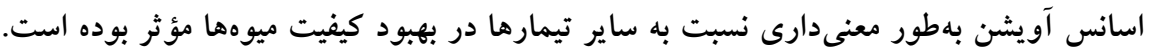

وازههاى كليدى: انغور، عمر بس از برداشت، فساد قارجى، كيفيت

1. استاديار، كروه علوم باغبانى، دانشكده كشاورزى و منابع طبيعى دانشكاه اردكان، اردكان، ايران

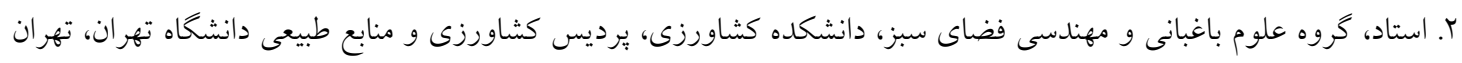

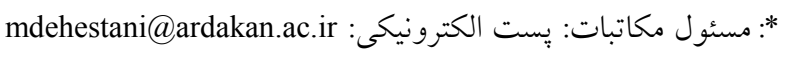


طول دوره انبارمانى به خصوص در هويجهاى يوشش داده شده

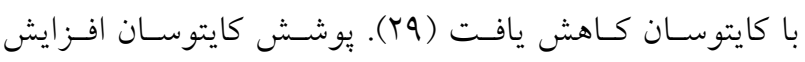

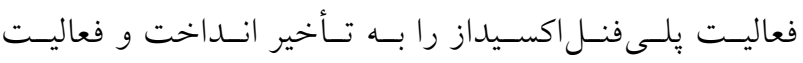

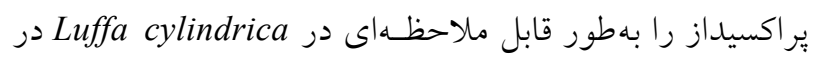

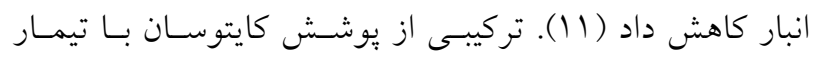

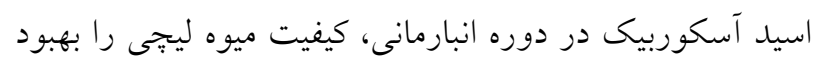

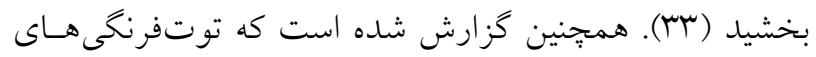
تيمار شده با كايتوسان كيفيت ميوه را با سطوح بالاتر فنل بهتر حفظ كـرد (4)). يوشـشهـاى كايتوسـان حساوى اسـانس در افزايش عمر تازه بلوبرىهاى تازه مؤثر بودند (سT). نشان داده

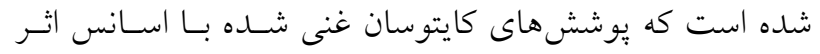

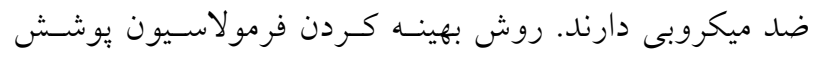
خوراكى كايتوسان همراه اسانس و كليسرول نيز توسعـه يافتـه

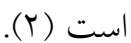
برخى يزوهشها اثر بازدارندگى اسانسها و اجزاى آنهـا در

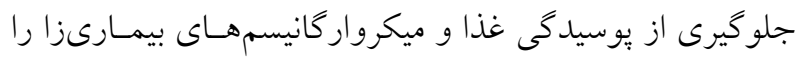

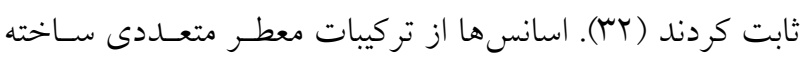

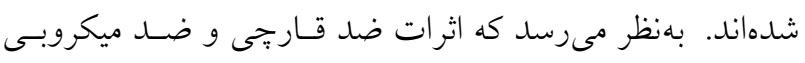

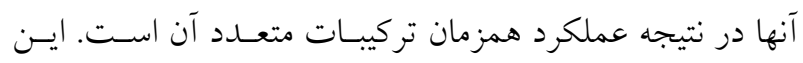

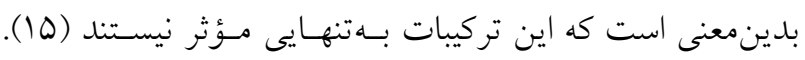

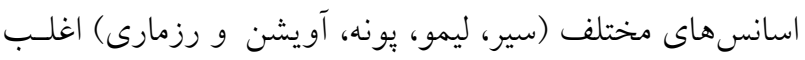

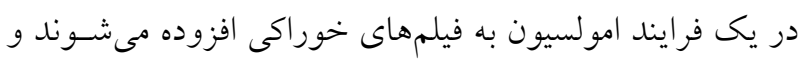

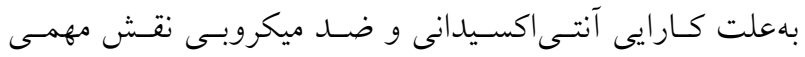
بهنوان مواد فعال بازى مى كنند (r). جنس تيموس كه در ايران

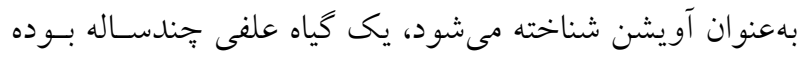

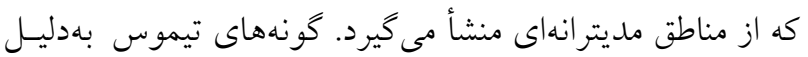

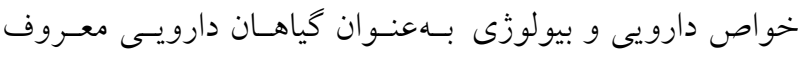

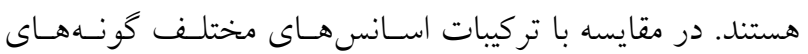
تيموس، يزووهش هاى انـدكى روى فعاليـتهـاى بيولـوزى آنهـا

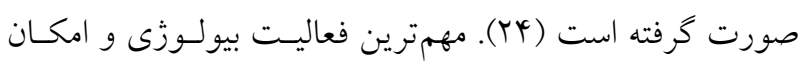

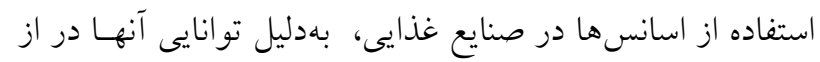

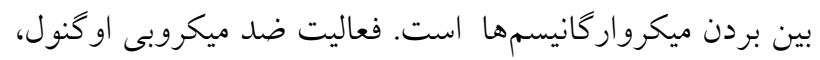

انكور ميوه نافرازگرا و بسيار فساديذير است كه بـهعلـت سفتى

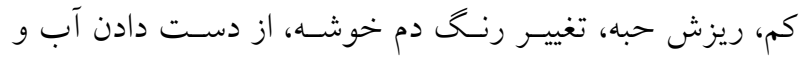

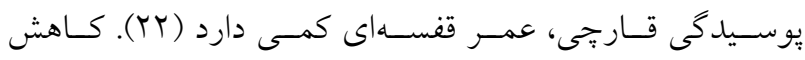

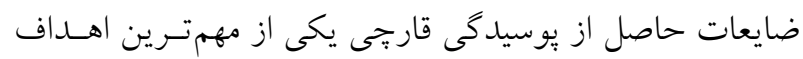

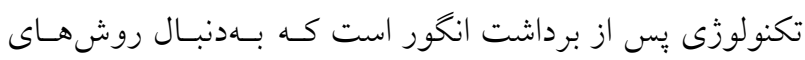

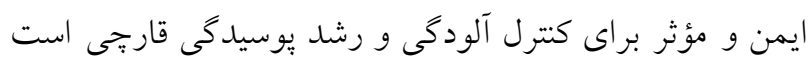

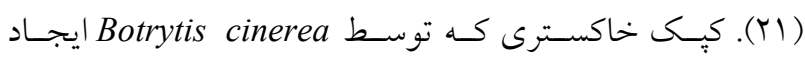

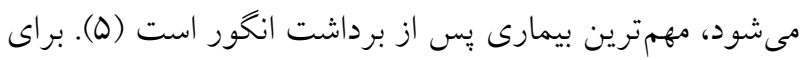

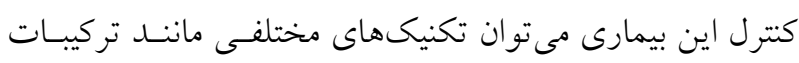

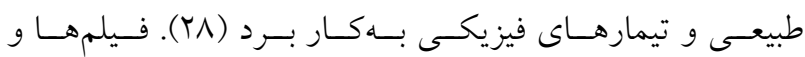

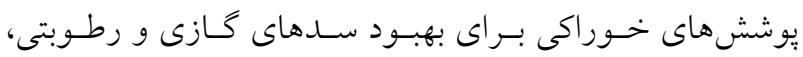

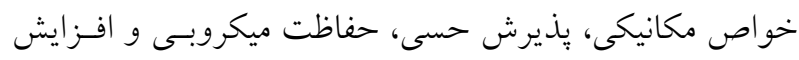

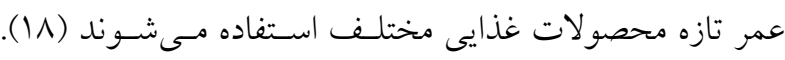

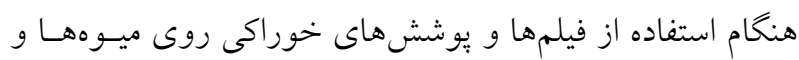

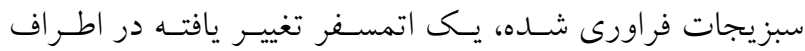

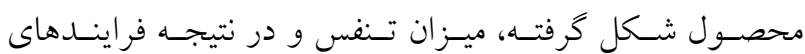
متابوليكى را كاهش مى دهد (YV) كايتوسان يك يليمر شبهطبيعى است كه بهصورت تجـارى

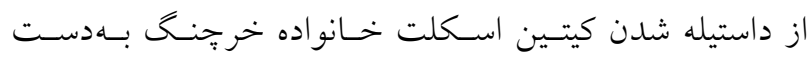

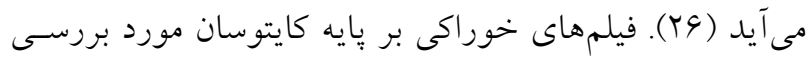

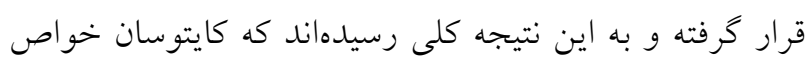

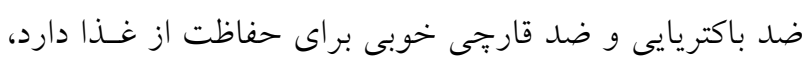

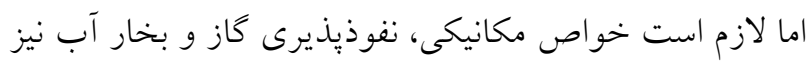

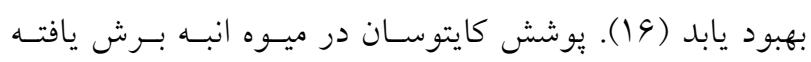

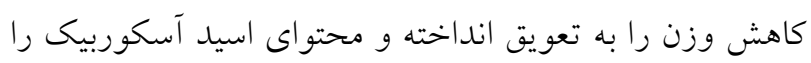

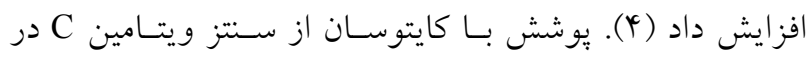

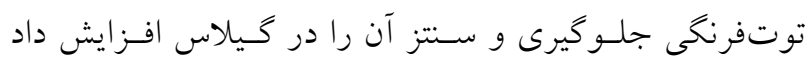

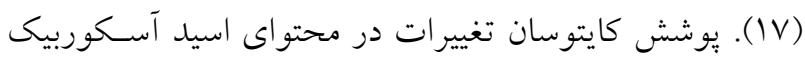
سه رقم كيلاس تيمار شده با كايتوسان Q/ه درصدة، انبار شــده

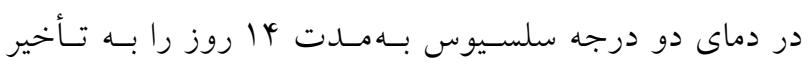

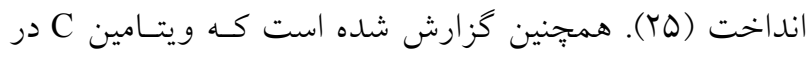


مقدار مواد جامد محلول حدود ها د درجه بريكس برداشت و بـهـ آزمايشخاه بِ از برداشت كروه علوم باغبانى برديس كشاورزى

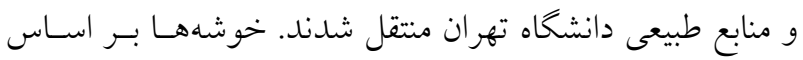
اندازه، رنخ و وزن انتخاب شده و حبههاى آلـوده و زخمسى از بين آنها حذف شد. يس از اعمال تيمارها ميوههــا بـه سـردخانه

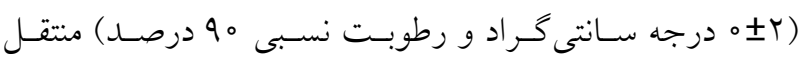

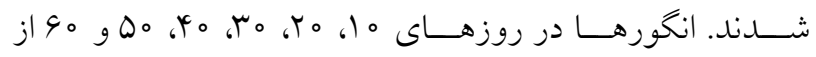
سردخانه خارج و در آزمايشخاه از نظـر صـفات كمّى و كيفى دوزى بررسى شدند.

تيمارهاى اعمال شده

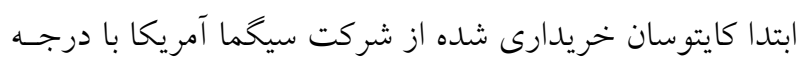

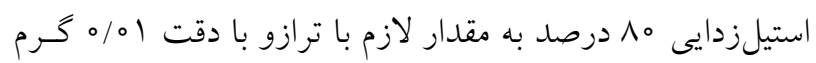
توزين و بهميزان لازم در ه 10

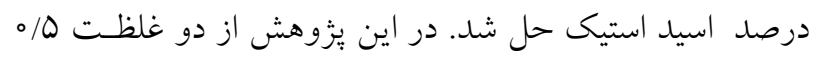

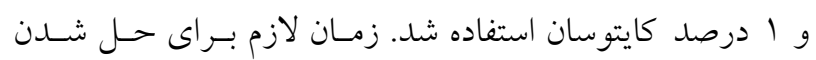
كايتوسان بستخى به وزن ملكولى و درجه استيلزدايسى آن دارد.

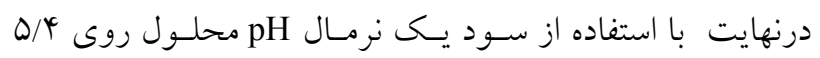
تنظيم شد. خوشهها بهمدت م9 ثانيه در محلول فروبرده شدند و

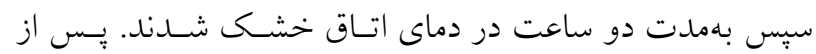

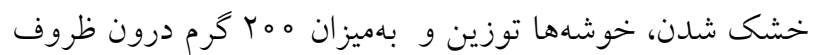

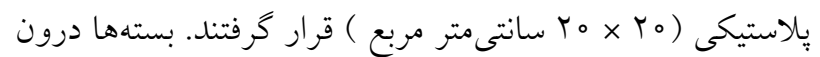

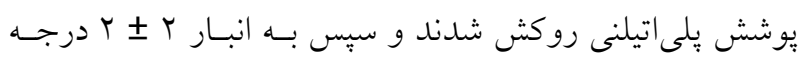
سانتى گر اد منتقل شدند (19). اسـانس آويشـن (Thymus vulgaris L.) مـورد اسـتفاده از شركت توليد و فراورى گياهان دارويى زردبند، خريسـارى شـــ. بامنظور تهيه محلول مورد استفاده براى فروبرى نمونسههـا،

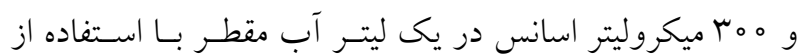
توئين هم به نسبت ه/ه درصد حل شد. بـ از فروبرى ميوههـا در محلول، آنها را روى طناب آويزان كرده تـا خشـك شــنـلد و

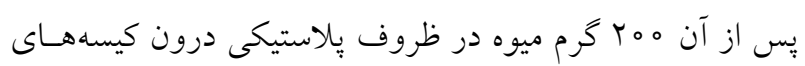
يلى اتيلنى قرار داده و به انبار منتقل شد (YV).
تيمول و كارواكرول عليه باكترىها، مخمرها و قارجها در محيط درون شيشه گزارش شده است. بر اين اساس، منتـول، او گنـول، كارواكرول و خصوصاً تيمول در كاهش درصد حبههاى آسـيب ديده كه بهطور مصنوعى با بوتريتيس سينرا (Botrytis cinerea) تلقيح شده بودند، بسيار مؤثر بودند، درحالى كه اكـالييتول اثـرى نداشت. بهعلاوه، بعضى بار امترهاى فيزيولــوزى انـــور از قبيـل توليد اتيلن و تنفس، در حبههاى تيمار شــده نسـبت بـه شـاهد

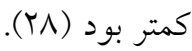
دىسوسا و همكاران (r/T) كزارش كردند كـه استفاده از اسـانس . Origanum vulgar L. روى انخــور توانسـت از رشــ ميسـيليومهــاى قـارجهـاى آسـيزيلوس و رايزويـوس در انبـار جلو گيرى كند (9). خاصيت سمى بودن اسـانس نـه تنهـا، عليـه ياتوزنهاى جانورى يا انسانى، بلكه براى حفاظت از محصولات باغبانى و دريايى نيز بسيار مهم اسـت. اسـانسهـا يـا بعضى از

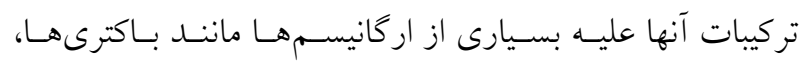

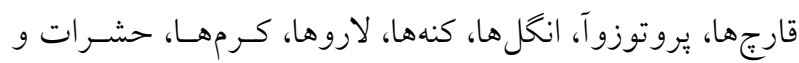
نرمتنان، مؤثر هسـتند (V)). داس سـانتوس و همكــاران (Yo|r) نشان دادند كه تيمار انخورهــاى برداشـت شــه بـا كايتوسـان و اسانس Origanum vulgare Lب بهور مؤثرى توانست از رشــ

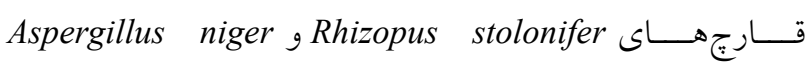

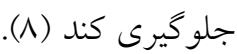
هدف از انجام يزوهش حاضر استفاده از كايتوسان، اسـانس آويشـن و تركيـب آنهـا بـهنهــوان جــايخزين مناسـبـ تركيبـات شيميايى بهمنظور افزايش عمر انبارمانى و حفـظ كيفيـت انحــور رقم "بيدانه قرمز" بود. همجنين اثر آنها بر برخـى خصوصسيات فيزيكى و فيزيكوشـيميايى و ارگانوليتيـك ميـوههـاى انخــور در زمان نخهارى در انبار بررسى شد.

\section{مو اد و روش ها تهيه مواد گياهى}

انخور رقم "بيدانه قرمز" از باغى در شهرستان تاكستان واقـع در استان قزوين برداشت شد. ميوهها در مرحله رسيدگى تجارى بـا 
قرار داده شد و محتواى مواد جامد (ساخت تايوان VBR-90A)

محلول بر اساس درجه بريكس بهدست آمد (بآن).

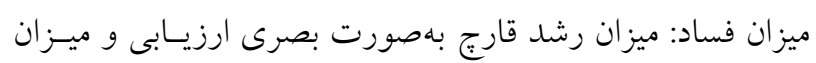
رشد قارج بهصورت درصد بيان شد.

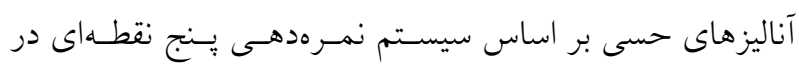
مقياس ه-ا صورت گرفت (YV).

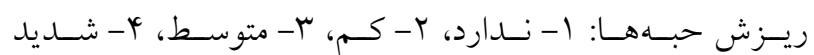
و ه- خ خيلى شديد

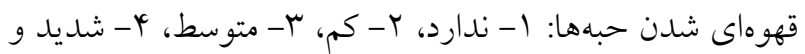

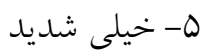
جروكيدكى حبهها: ا- خيلسى تروكيـده، ץ- كمسى تروكيـده،

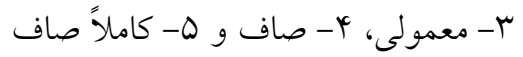

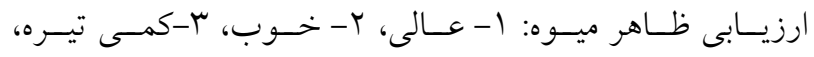

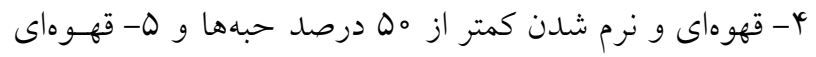
و نرم شدن بيشتر از 00 درصد حبه تهائ

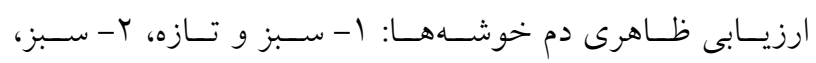

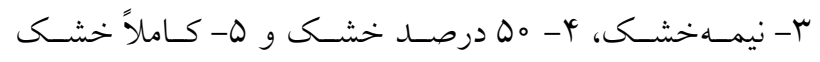
ارزيابى حبههاى خرد شده و از بين رفته: براى اين منظور تعداد

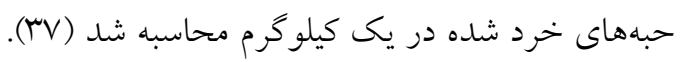

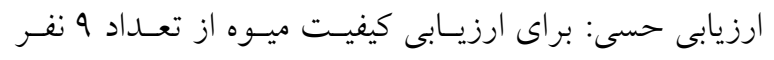

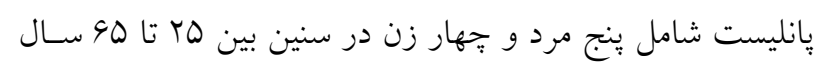

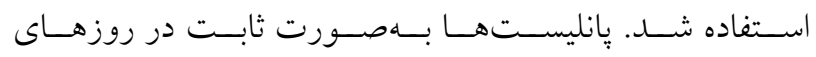

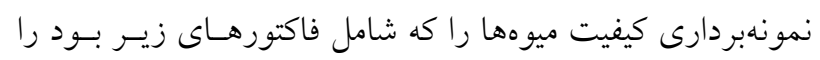

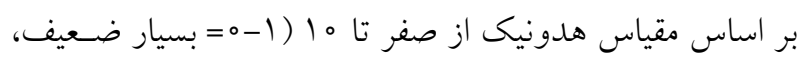

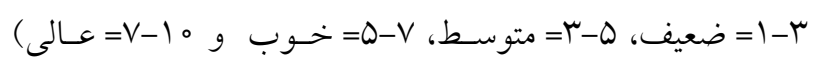

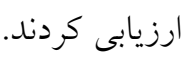

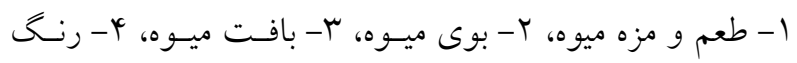

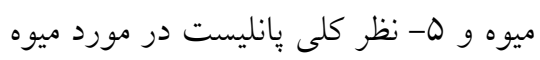

\section{طرح آزمايشى}

اين آزمايش بهصورت فاكتوريل در قالب طـرح كـاملاً تصـادفى إنى

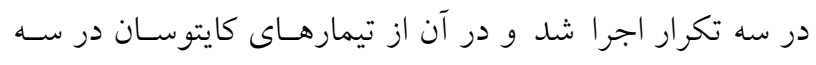

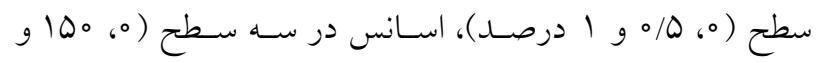

براى تهيه محلولهاى تركيبى ابتدا محلول كايتوسان بـه روشى في

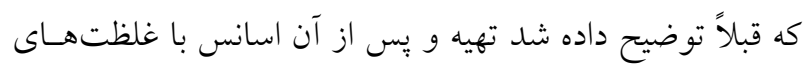

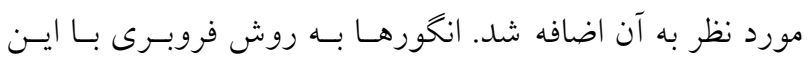
محلول تيمار و يس از خشك شدن، بسته بندى و به انبار منتقل

شلنل.

\section{شاخص هاى مورد بررسى}

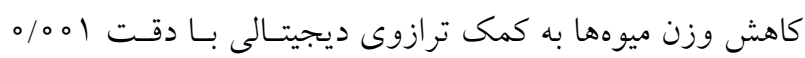

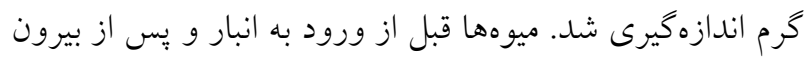

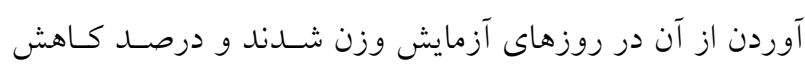
وزن با استفاده از رابطه (1) محاسبه شد.

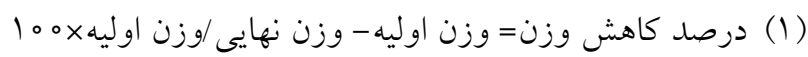

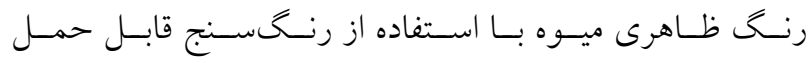
(Minolta CR400 Japan)

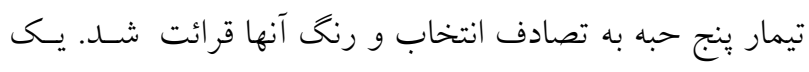

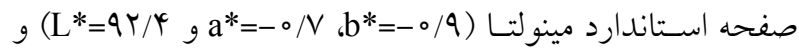

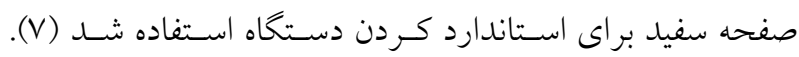

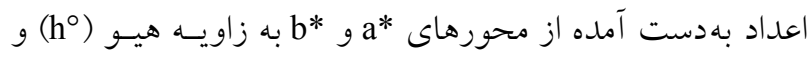
شاخص اشباع (C) (كروما) تبديل شدند.

كه ○ م= قرمز - صورتى،

$\mathrm{h}^{\circ}=\operatorname{arctangent}\left(\mathrm{b}^{*} / \mathrm{a}^{*}\right)$

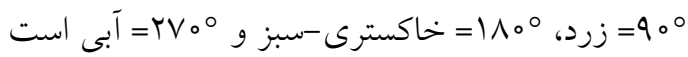

شاخص اشباع شدت يا خلوص هيو را نشان مىدهـــ و هرجيـه

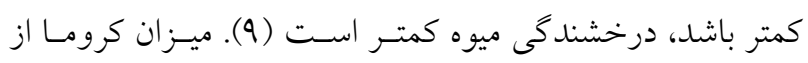
رابطه (r) بهدست آمد:

$\mathrm{C}=\left(\mathrm{a}^{* r}+\mathrm{b}^{* r}\right)^{1 / r}$

يس از تنظيم pH متر با محلولهاى بافر جهار و هفت، محلـول

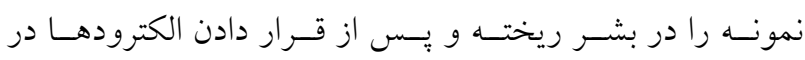

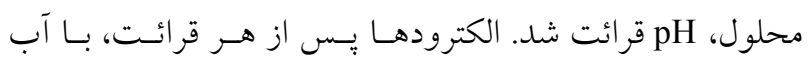

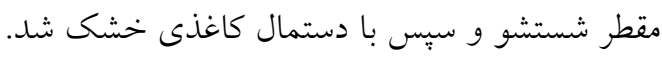

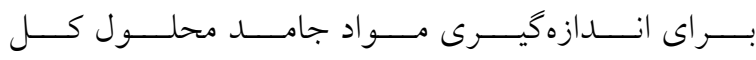

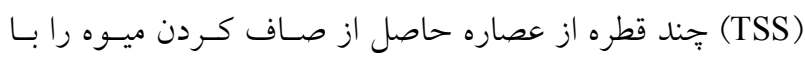

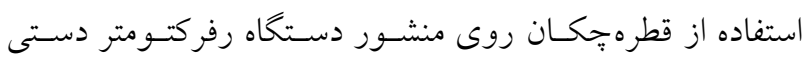


جدول l. تركيبات شناسايى شده در اسانس آويشن باغى با دستخاه (GC/MS)

\begin{tabular}{|c|c|c|c|c|c|}
\hline زمان بازدارندگى & درصد & تر كيبات & زمان بازدارندگى & درصد & تركيبات \\
\hline$I T / T \Lambda$ & $4 / 99$ & كاما - تريينن & $9 / \circ r$ & $0 / 19$ & آلفا- بينن \\
\hline $1 \pi / 09$ & $\circ / \circ \mathrm{V}$ & آلفا- تريينولن & $9 / 4 T$ & $\circ / 1$ & كامفن \\
\hline $\mid r / T \Delta$ & $\circ / 4 \circ$ & لينالول & $10 / T \Lambda$ & - & ميرسن \\
\hline $14 / 94$ & $0 / 04$ & كامغور & $10 / \mathrm{VV}$ &.$/ 04$ & آلفا- فلاندرن \\
\hline$M / M$ & $9 \mathrm{~V} / 9 \mathrm{r}$ & تيمول & $11 / 11$ & O/QF & آلفا- تريينن \\
\hline$T Y / D$ & $\circ / V^{4}$ & بتا- آريوفيلن & $11 / \mu \wedge$ & TYM & يى - سيمن \\
\hline Tr/TG & \% & دى - جرماسرن & $11 / 49$ & $0 / 1 T$ & ليمونن \\
\hline TY/Ar & $\circ / \circ$ & سياتولنول & $11 / 00$ & $0 / 09$ & بتا- فلاندرن \\
\hline
\end{tabular}

ندادند. بيشترين كاهش وزن در روز ه9 انبارمانى (ه/ه درصد) به دست آمد. در ميان تيمارهاى مختلف بيشترين كاهش وزن در نمونههاى شاهد (بـدون تيمـار) (او/ه درصـد) بـهدست آمــد (جدول \&). با اعمال تيمارهاى مختلف ميزان از دست دادن آب نمونهها بهطور معنى دارى كاهش يافت. بـهـــورى كـه كمتـرين كاهش وزن در ميوههاى تيمار شده با ه/ه و ا درصد كايتوسـان

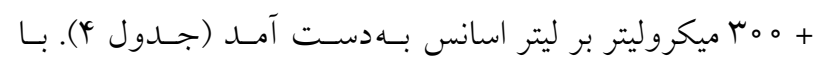
كذشت زمان و تشديد تبخير و تعرق بهدليل عدم يكسان بـودن فشار بخار آب ميان فضاى بين سلولى بافتهاى ميوه و اتمسـفر

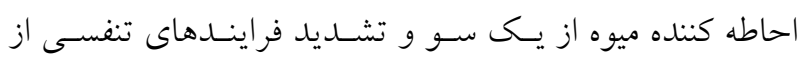
سوى ديخر، كاهش وزن در طى زمـان امـرى طبيعى اسـت. از طرفى بالاتر بودن ميـزان كـاهش وزن در نمونسههـاى شـاهد را مىتوان به تهويه بهتر و شرايط مساعدتر براى انجام فراينـدهاى تنفسى نسبت داد ( (). بهطسوركلى تيمارهـا بهتـر از شـاهد وزن اوليه خود را حفظ كردند. نتايج حاصل از بوششدهى انخورهـا بـا كايتوسـان و اسـانس بـذر كريسِ فـروت كـهـ توسـط زو و همكاران صورت گرفت نيز نشان داد كه ميوههـاى تيمـار شــه نسبت به شاهد كاهش وزن كمترى داشتند. همجنــين آنهـا بيـان كردند كه با كذشت زمان ميزان كـاهش وزن، افـزايش مسىيابـــ

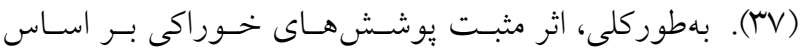
خو اص هيخروسكويى است كه بهعنوان سدى بين ميوه و محيط اطر اف قرار دارد، بنـابراين تبـادلات خـارجى را كـاهش داده و
ه ميكروليتر بر ليتر) و تركيـب كايتوسـان و اسـانس در رقـم "بيدانه قرمز" هر كدام با سه تكرار اسـتفاده شـد. تيمـار شـاهد بلدون تيمار با اسانس و كايتوسان با سه تكرار در نظر گرفته شد. در مورد دادههاى يُرامتريك از آزمون توكى استفاده شـــ. بـراى تعيـين تفــاوت ميـان تيمارهــاى مختلــف در مـورد دادههــاى نانيارامتريك مانند ظاهر حبهها از آزمون Mann-Whitney U و

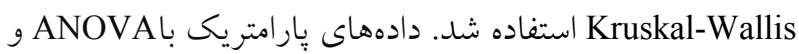

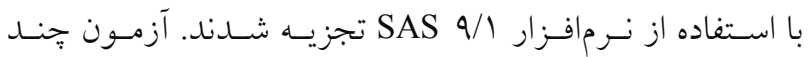
دامنهاى دانكن براى تعيين معنى دار بــودن تفــاوت آمـارى ميـان ميانخين تيمارها در سطح احتمال ينج درصد انجام شد.

\section{نتايج و بحث}

نتايج حاصل از آناليز اسانس آويشن بـا دســخاه كرومـاتوگر افى كازى همر اه با طيـفسـنجى جرمسى (GC/MS) در جــدول (1) آورده شده است. همانطـور كـهـه در جــدول مشـاهلده مسىشـود تيمول با 9V/9 درصد بالاترين ميزان ماده مـؤثره اسـانس گيـاه آويشن را تشكيل داده است. بر اساس نتايج بهدست آمده اثر زمان بر كاهش وزن ميوههـا

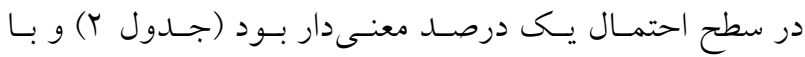

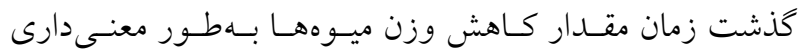
افزايش يافت (جدول r). نمونهها تا روز مب نخهدارى در انبـار كاهش وزن معنسى دارى نسـبت بـهـ زمـان آغـاز آزمـايش نشـان 
جدول r. نتايج تجزيه واريانس دادهاى حاصل از اندازهيرى شاخصهاى كمى در رقم "بىدانه قرمز"

\begin{tabular}{|c|c|c|c|c|c|c|c|c|c|}
\hline & & & & مربعات & ميانگين & & & & \\
\hline خردشدگى & زاويه & $b^{*}$ & $a^{*}$ & فساد & $\mathrm{pH}$ & جامد محلوان مواد & كاهش وزن & $\mathrm{df}$ & منابع تغييرات \\
\hline$\Gamma / \circ \Delta^{* *}$ & $\circ / \circ Y^{*}$ & $\varphi / 9 \wedge^{* *}$ & $r / r_{\circ} \mathrm{ns}$ & $1 / M^{* * *}$ & $\circ / \Lambda Y^{* *}$ & $\Lambda / 01^{* *}$ & $r \Delta \circ \circ Y / \circ \Gamma^{* * *}$ & 4 & زمان \\
\hline$\circ / 9 V^{* *}$ & $\circ / 1 r^{* *}$ & $\varphi / \mu \mu^{* *}$ & $\Lambda / \mathcal{\varphi} \Delta^{\mathrm{ns}}$ & $1 / 91^{* *}$ & $\circ / \mu^{n s}$ & $r_{\circ} / V^{* *}$ & YYVV/OYns & r & كايتوسان \\
\hline$\circ / / r^{\mathrm{ns}}$ & $\circ / \circ \wedge^{*}$ & $|r / 9|^{* *}$ & $\varphi / \mu_{\circ} n s$ & $\circ / 10^{* *}$ & $\circ / 0 y^{\mathrm{ns}}$ & $|c| / V^{* *}$ & $Y V Y Q / \backslash \Lambda^{n s}$ & r & اسانس \\
\hline$\circ / \circ V^{n s}$ & $\circ / 0 Y^{\mathrm{ns}}$ & $1 / 91^{* *}$ & $1 / V Y^{\mathrm{ns}}$ & $\circ / \circ 9^{* *}$ & $\circ / \circ 4^{* *}$ & $\Delta / 9 r^{* *}$ & ro99/VVns & ir & كايتوسان × زمان \\
\hline$\circ / 0 y^{\text {ns }}$ & $\circ / \circ r^{n s}$ & $1 / Y_{\circ} \mathrm{ns}$ & $r / 4 y_{n s}$ & $0 / 09$ & $\circ / \circ \Delta^{* *}$ & $r / \mu_{\circ} n s$ & $r Y q Y / 1 q^{\mathrm{ns}}$ & ir & اسانس ×زمان \\
\hline$\circ / q^{* *}$ & $\circ / \circ 4^{*}$ & $9 / \mu r^{* * *}$ & $\operatorname{lT/M\varphi ^{**}}$ & 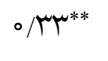 & $\circ / 01^{\mathrm{ns}}$ & $\Delta T / \Delta Y^{* *}$ & IVYV/FF* & r & كايتوسان × اسانس \\
\hline$\circ / \circ V^{n s}$ & $\circ /\left.0\right|^{\mathrm{ns}}$ & $\circ / \Lambda Y^{n s}$ & $1 / 4 \wedge^{\mathrm{ns}}$ & $\circ / \circ \Delta$ & $\circ / \circ r^{*}$ & $r / 9 \mu^{\mathrm{ns}}$ & $|0 \mathrm{~V}| /||^{\mathrm{ns}}$ & YY & كايتوسان × اسانس × زمان \\
\hline$\circ / \circ \Delta$ & \%०r & $\circ / \wedge \Delta$ & $r / \Delta^{\circ}$ & $\circ \%$ & $0 / 0 Y$ & $Y / Y \backslash 1$ & $10 K 4 / I V$ & $11 \mathrm{r}$ & خطاى آزمايشى \\
\hline ro/Ar & $4 / 99$ & TVQ/OT & $D \circ r / \Delta \varphi$ & TY/D。 & $9 / 7 q$ & $\Lambda \Lambda Y / T Q$ & DYAYG $/ 90$ & $1 M 1$ & كل \\
\hline $19 / 0 T$ & $|N / 4|$ & $14 / 90$ & $Y T / 9 V$ & $19 / 0 \circ$ & $r / 4 q$ & $\Delta / V q$ & $19 / 10$ & & C.V\% \\
\hline
\end{tabular}

جدول r. اثر مدت زمان نخهدارى بر برخى صفات كمى انخور رقم "بيدانه قرمز"

\begin{tabular}{|c|c|c|c|c|c|c|c|c|c|}
\hline خرد شدكى حبه (تعداد/كيلوكرم) & كروما & زاويه هيو & $b^{*}$ & $a^{*}$ & رشد قارج & $\mathrm{pH}$ & 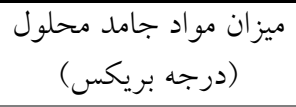 & كاهش وزن & زمان \\
\hline $1 / 0 o^{d}$ & $10 / \circ \Delta^{a}$ & $\circ / \wedge)^{b}$ & $9 / 9 \wedge^{\mathrm{a}}$ & $V / \varphi^{c} \circ a$ & $\circ / \circ \circ f$ & $\varphi / \circ \Delta^{a}$ & $r \& / 4 \varphi^{\mathrm{a}}$ & o/०od & $\circ$ \\
\hline $1 / 19 \mathrm{c}$ & $9 / 9 r^{a}$ & 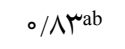 & $4 / 19 a$ & G/AYa & $\circ / \mu q$ ef & $r / \wedge \circ b$ & $r G / \pi_{\circ} a b$ & $\circ / 1 \circ d$ & 10 \\
\hline $1 / T T^{c}$ & $q / Y q^{a b}$ & $\circ / \wedge q^{a b}$ & $\varphi / r \wedge^{\mathrm{a}}$ & V/Dra &.$/ 99^{\mathrm{e}}$ & 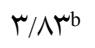 & $r \Delta / V \Delta^{\mathrm{ab}}$ & $\circ /\left.Y\right|^{\mathrm{cd}}$ & ro \\
\hline$\left|/ 4^{\mathrm{c}}\right|^{\mathrm{b}}$ & $Q / \Delta \wedge^{a b}$ & $\circ /\left.\Lambda\right|^{b}$ & $\varphi / 4 \Delta^{a}$ & $G / \Lambda^{a}$ & $1 / T Y^{d}$ & $r / V^{b}$ & $r Q / V \circ a b$ & $\circ / \mu \mu_{c}$ & r。 \\
\hline $1 / 4 \Delta^{b}$ & $9 / \mu r^{\mathrm{ab}}$ & $\circ / \wedge)^{b}$ & $G / T Y^{a}$ & $9 / N r^{\mathrm{a}}$ & $r / l^{c}$ & $\mathrm{r} / 99^{\mathrm{c}}$ & $r d / Y y a b$ & $\circ / 4 \circ b$ & $\psi_{0}$ \\
\hline $1 / N 9^{a}$ & $q / \circ V^{a b}$ & $\circ / \Lambda \mu^{a b}$ & $9 / 0 r^{\mathrm{a}}$ & $9 / 99^{\circ}$ & $r / \varphi_{0} b$ & $r / \Delta V^{d}$ & $r d / I r^{\mathrm{ab}}$ & $\circ / 4 T^{b}$ & Q. \\
\hline $1 / q^{a}$ & $\Lambda / N Y^{b}$ & $\circ / 9 \circ a$ & $\Delta / \mu^{b}$ & G/VGa & $\Delta / \uparrow q^{a}$ & $\mu / \Delta \gamma^{\alpha d}$ & $r Q / \circ Y^{b}$ & $\circ / \Delta \Delta^{a}$ & 90 \\
\hline
\end{tabular}

در هر ستون ميانخين هايى كه حداقل در يك حرف مشترى هستند تفاوت معنىدارى در سطح ينج درصد آزمون LSD ندارند.

جدول f. اثر اسانس، كايتوسان و اثر متقابل آنها بر برخى صفات انخور رقم "بيدانه قرمز"

\begin{tabular}{|c|c|c|c|c|c|c|c|c|c|c|}
\hline خردشد (تعداد كيلو حرم) هبها & 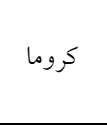 & زاويه & $b^{*}$ & $a^{*}$ & 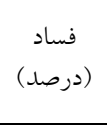 & $\mathrm{pH}$ & مواد جامد محلول & وزن (درصد) & كايتوسان & 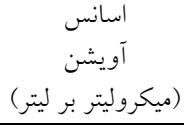 \\
\hline$q / r q^{a}$ & $V / 9 \Delta^{d}$ & 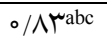 & $\Delta / T \Delta^{d}$ & $\Delta / \Lambda Y^{q d}$ & $\Delta / \circ q^{a}$ & $r / \Lambda l^{a}$ & $T Y / \mu T^{d}$ & $0 / 91^{a}$ & $\circ$ & $\circ$ \\
\hline $9 / 0 V^{b c}$ & $1 \circ / Y_{0} a^{a}$ & $\circ / \wedge q^{a}$ & $9 / \mu y b$ & $V / 91^{a}$ & $r / v \varphi^{a b}$ & $r / V^{a b}$ & $T G / T V^{c}$ & $\circ / 4 y b$ & 。 & 100 \\
\hline$\Delta / \Delta Y^{c d}$ & $10 / 4 \varphi^{a}$ & $\circ / V y^{c c}$ & $V / D)^{a}$ & $V / / 0^{a b c}$ & $r / \Delta V^{b}$ & $r / V \mu^{\mathrm{ab}}$ & $Y Y / \Delta Q^{d}$ & $\circ / \wedge^{b c}$ & $\circ$ & roo \\
\hline r/Yyde & $q / 4 y b c$ & $\circ / 9 \mu^{a}$ & $0 / 9)^{\mathrm{cd}}$ & V/Drab & $\circ / 9 \Delta^{c}$ & $\mu / V^{a b}$ & $r V / q \mu^{a}$ & $\circ / \mathbb{A} Y \mathrm{bc}$ & $\circ / 0$ & 。 \\
\hline$r / l$ de & $\mathrm{q} / \mathrm{M}^{\mathrm{ab}}$ & $\circ / \wedge D^{a b c}$ & $9 / 4 \mathrm{rb}^{\mathrm{b}}$ & $V / r V^{a b}$ & $\circ / I^{c}$ & $r / V^{b}$ & $r Y / G Y d$ & $\circ / \sim q b c$ & $\circ / 0$ & 100 \\
\hline$r / 9 Y^{\mathrm{e}}$ & $q / \Gamma \Delta^{b c}$ & $\circ / \wedge q^{a}$ & $\Delta / \Delta V^{c d}$ & $\mathrm{~V} / \mathrm{IV} \mathrm{V}^{\mathrm{abc}}$ & $\circ / 9 \Delta^{c}$ & $r / V \Delta^{a b}$ & TG/VGbc & $0 / T \mu^{c}$ &.$/ 0$ & roo \\
\hline$Y / Y Y$ cde & $q / \mu \wedge b c$ & $\circ / \wedge V^{a b}$ & $0 / 9 \nvdash b c$ & $V / I V^{a b c}$ & $1 / \circ \circ \mathrm{c}$ & $r / V \Delta^{\mathrm{ab}}$ & $r V / \Delta \varphi^{a b}$ & $\circ / \mu / b c$ & 1 & $\circ$ \\
\hline$r / V l^{\mathrm{de}}$ & $q / \wedge^{\mathrm{bc}}$ & $\circ / V \wedge^{\mathrm{bc}}$ & $9 / 0 r^{\mathrm{b}}$ & $\varphi / \Delta \Delta^{\mathrm{bcd}}$ & $\circ / \Gamma \Lambda^{c}$ & $r / N \circ b$ & $T Y / Y \varphi^{\mathrm{d}}$ & $\circ / T^{b c}$ & 1 & 100 \\
\hline T/re & $\Lambda / \Lambda \Lambda^{\mathrm{c}}$ & $\circ / \mathrm{V} V^{b c}$ & $q / q^{b}$ & $9 / 19 \mathrm{~cd}$ & $\circ / T \Delta^{c}$ & $r / V \mu^{\mathrm{ab}}$ & $Y Y / \Lambda Y^{d}$ & $\circ /\left.Y\right|^{c}$ & 1 & r。o \\
\hline
\end{tabular}


به قند را نيز بخيرد، در واقع اكسيزن هوا، كربوهيدراتهـا را بـه

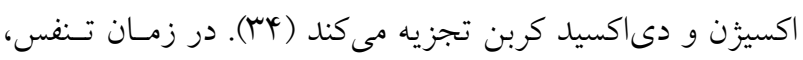

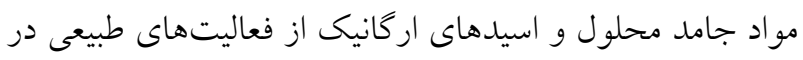

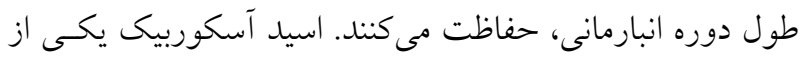

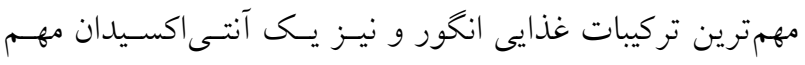

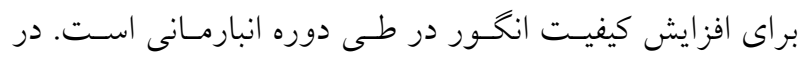

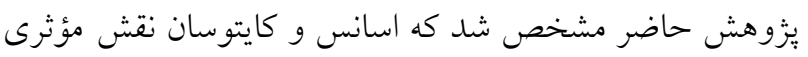

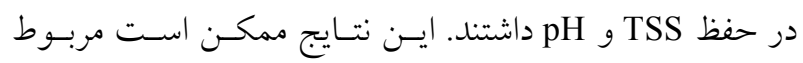

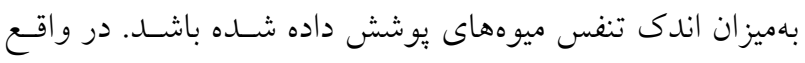

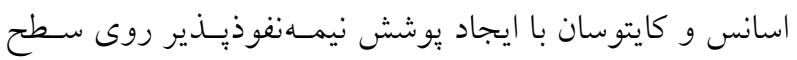

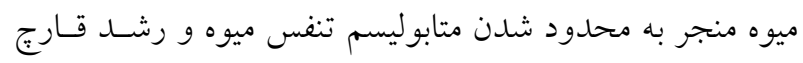

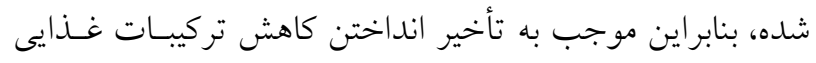

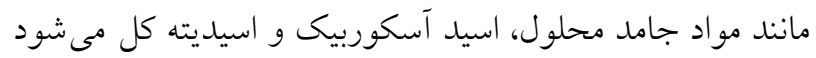

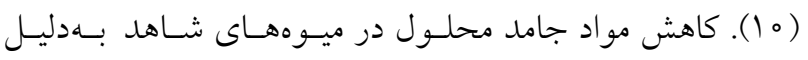

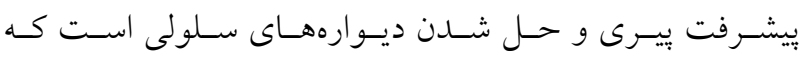
بهصورت مواد جامد محلول در مى آيند.

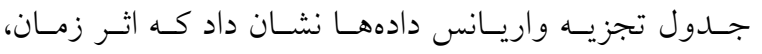
كايتوسان، اسانس و اثر متقابل كايتوسان در زمان و كايتوسان در

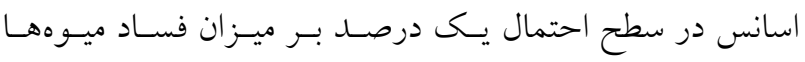

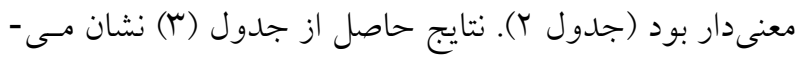

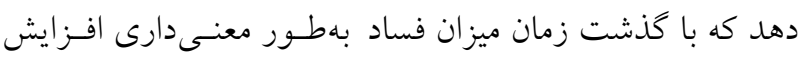

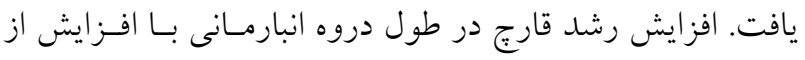

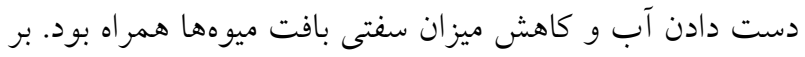

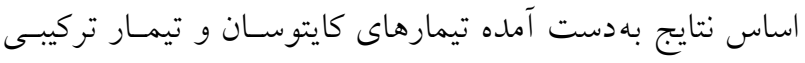
كايتوسان و اسانس بلهور مطلـوبى نسـبت بـه شـاهد تو انسـتند

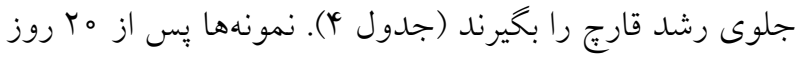

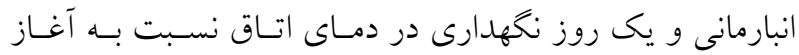
آزمايش افز ايش معنىدار در ميزان فساد نشـان دادنــــ مـارتينز رومرو و همكاران بيان كردند كه افـزودن كـارواكرول بـهـ درون

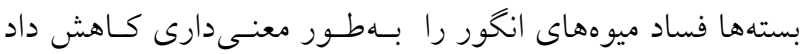

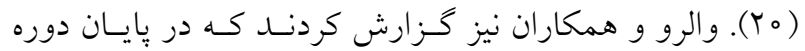

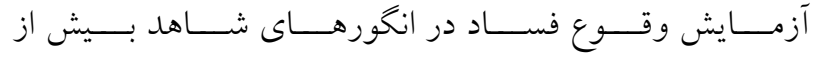
هD درصد بود، درحالى كه بـا اضـافه كـردن تيمسول و اوكَنـول
درنهايت مانع از دست دادن آب ميوهها مىشود (TV).

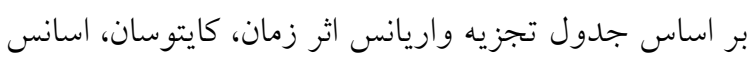

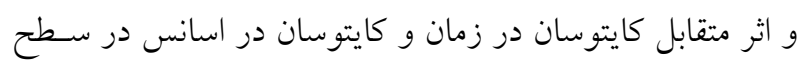

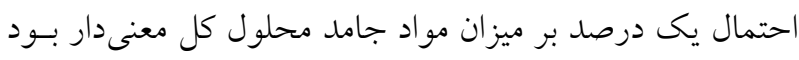

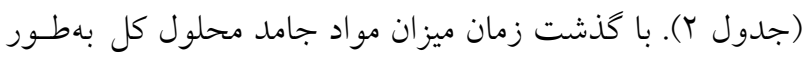

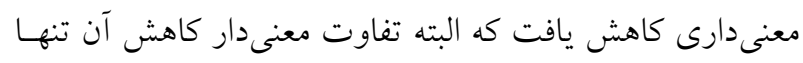

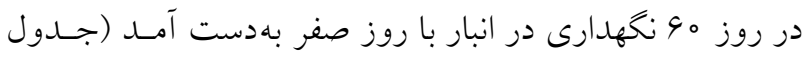

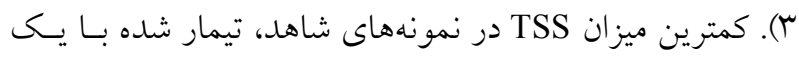

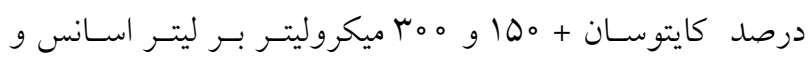

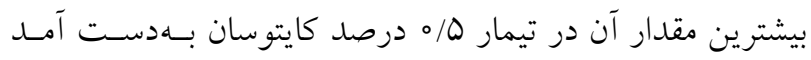

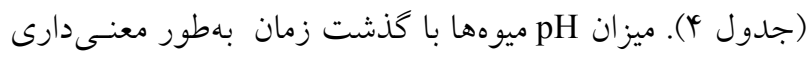

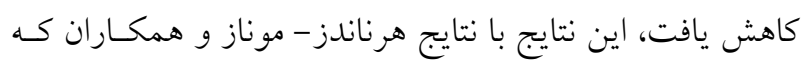

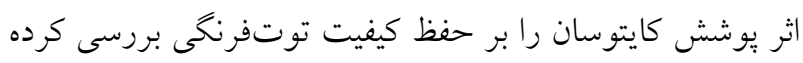

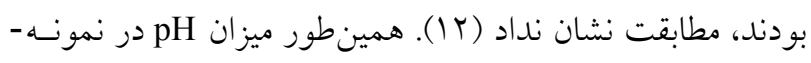
هاى تيمار شده با اسانس بهتنهايى و كايتوسان به تنهايى با شاهد

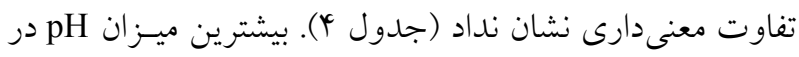

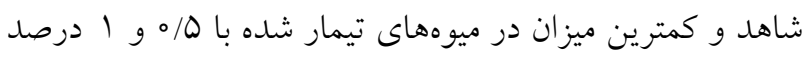

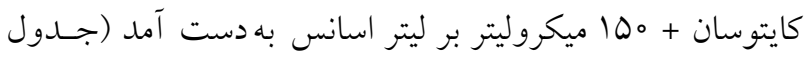

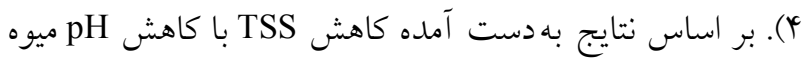

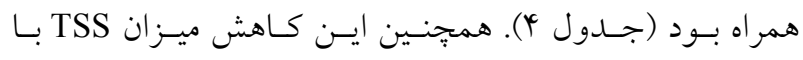

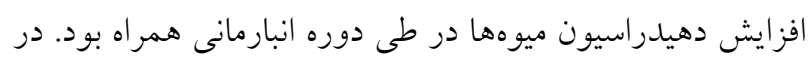

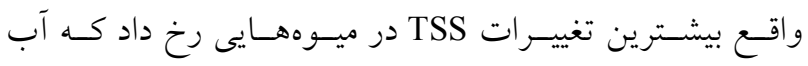

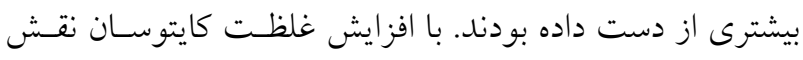

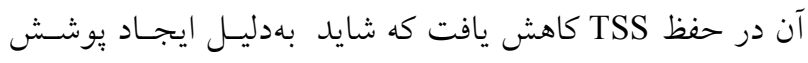
ضخيم روى ميوه و ايجاد حالت تنفس غير هـوازى در ميـوهــا

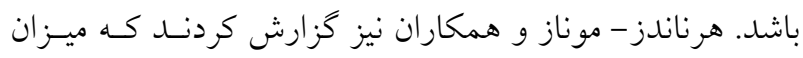

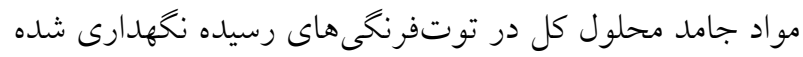

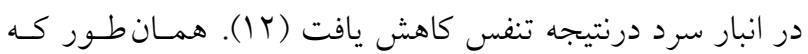

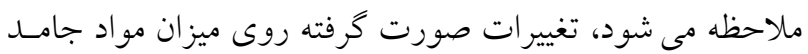

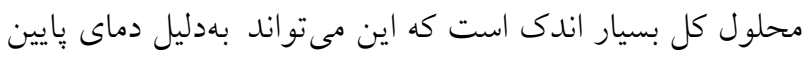

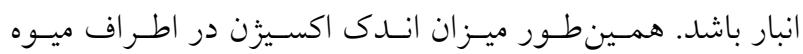

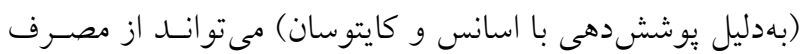
قندها جلو گيرى كند و درنتيجه جلوى متابوليسم تبديل نشاسـته 
نمونههاى تيمار شده با مب ميكروليتر بر ليتر اسانس و بيشترين

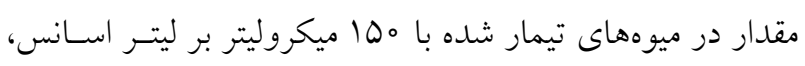

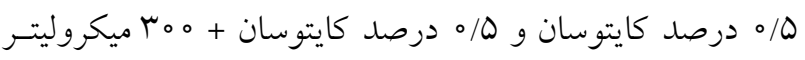

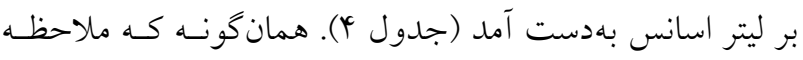

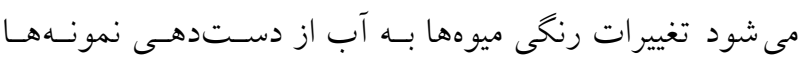

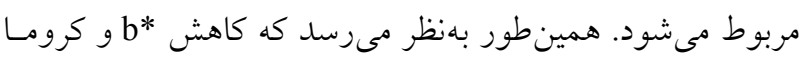

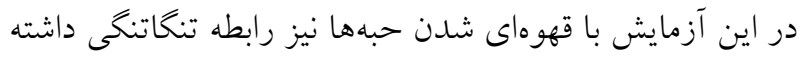

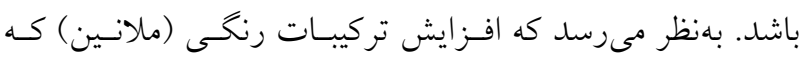

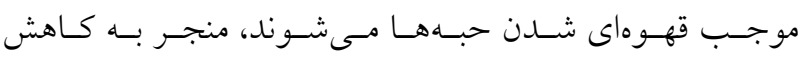

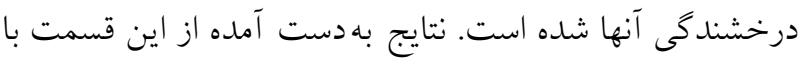

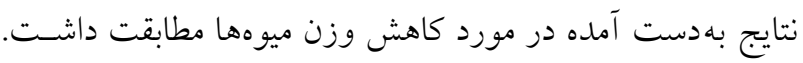

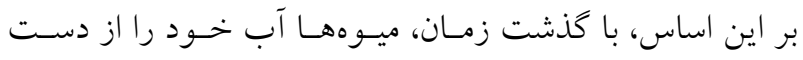

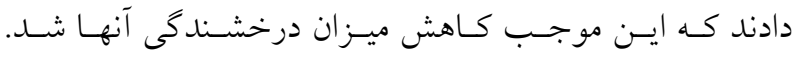

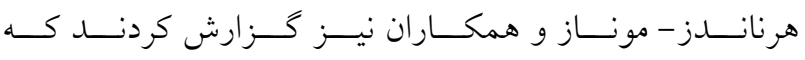

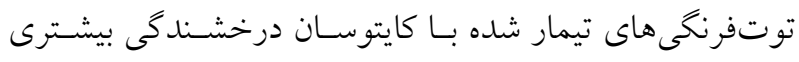

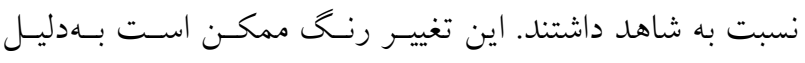
افزايش سرعت تنفس و تحريك فعاليـتهـاى آنزيمسى، شـامل

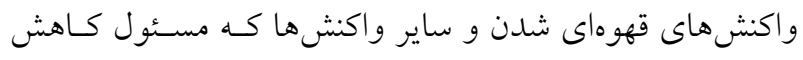

كيفيت ميوه هستند، باشد (9). بر اساس جدول تجزيه واريانس اثر زمـان، كايتوسـان و اثـر مئر

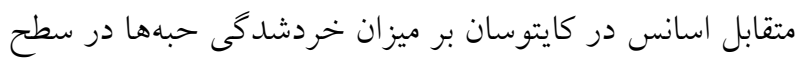

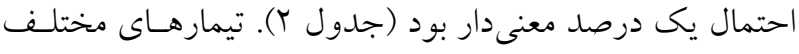

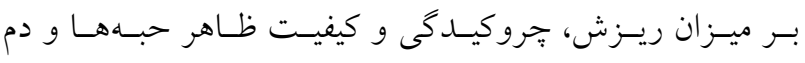

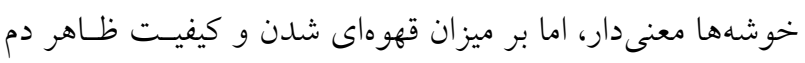

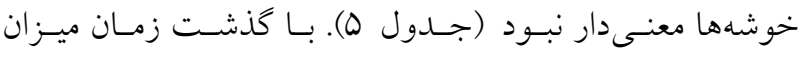

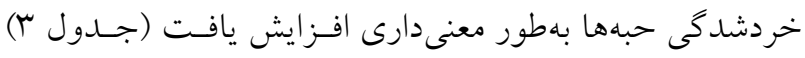

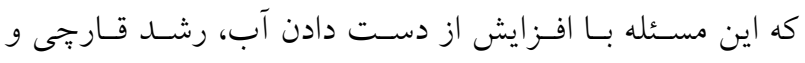

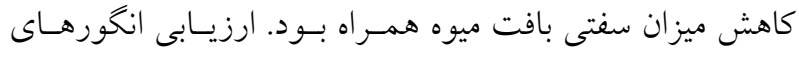

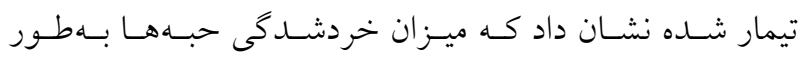

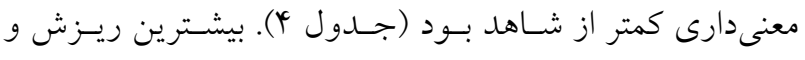

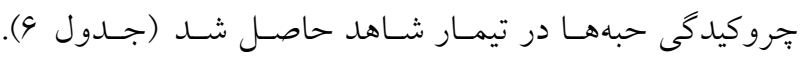

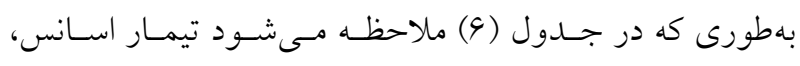

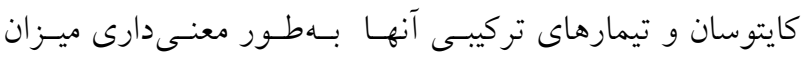

ميزان فساد بهطور معنى دارى كاهش يافت. بهعلاوه، بـا افزايش غلظت اسانس و غلظت كايتوسان ميزان فساد نيز كاهش بيشترى

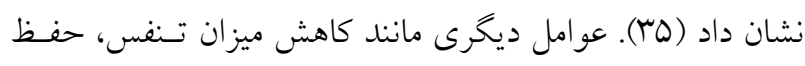

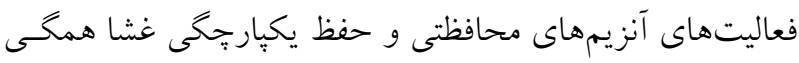

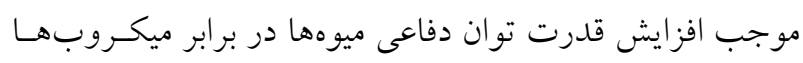

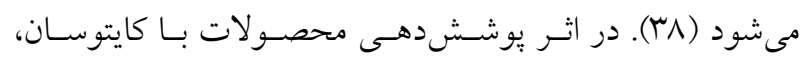
شانس تماس ميكروببها با سطح ميـوه كـاهش يافتـه، بنـابراين

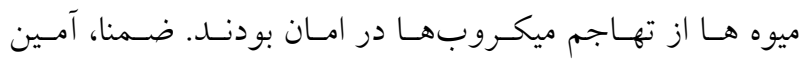

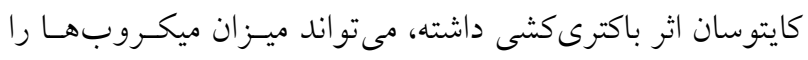

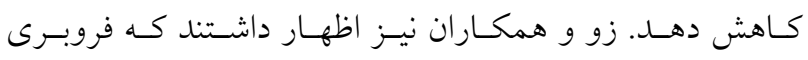

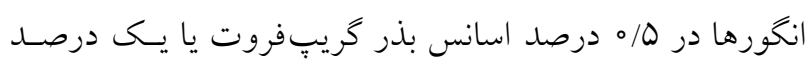

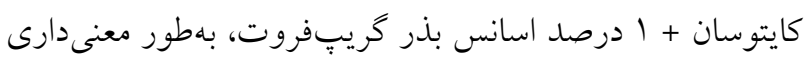

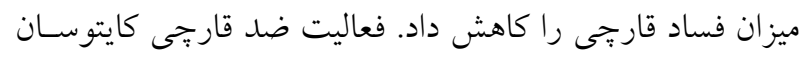

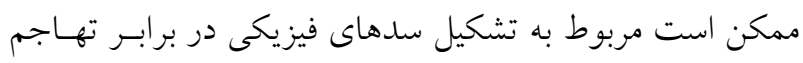

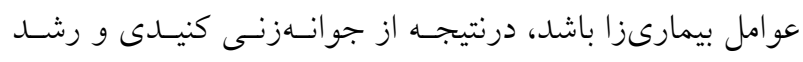

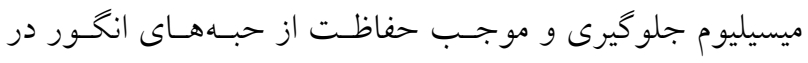

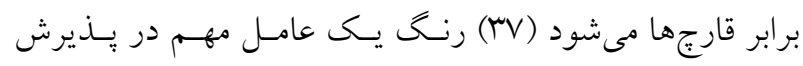

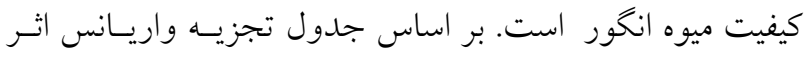

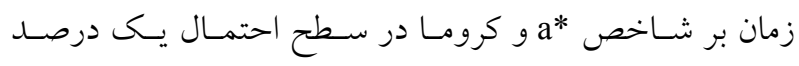

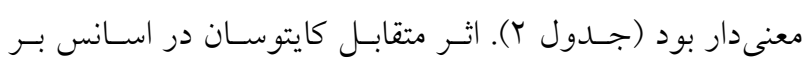

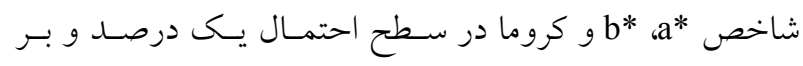
زاويه هيو در سطح احتمال ينج درصد معنى دار بود (جــدول r ب).

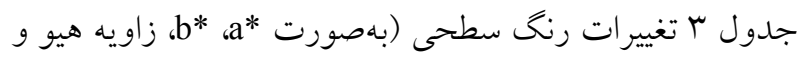

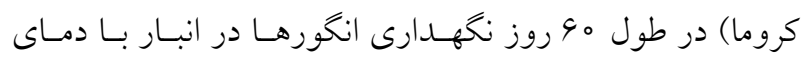

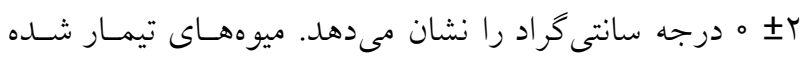

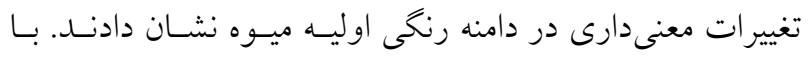

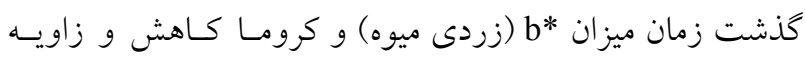

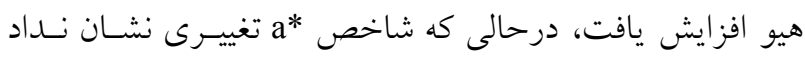

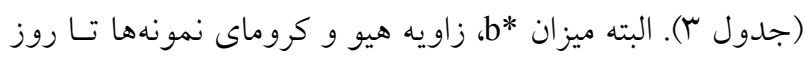

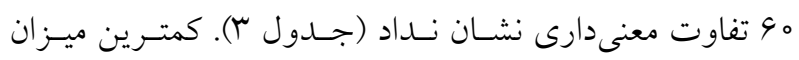

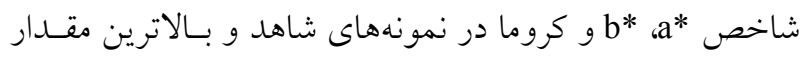

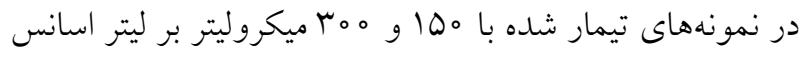
مشاهده شد (جدول \&). همجنين كمترين ميـزان زاويـهـ هيـو در 
جدول ه. بررسى برخى صفات كيفى انگور بر اساس آزمون كروسكال واليس رقم "بيدانه قرمز"

\begin{tabular}{|c|c|c|c|c|c|c|c|c|c|}
\hline يظانليست كلى & بافت & رنگ & طعم و مزه & ظاهر & ظاهر دم شهدا & 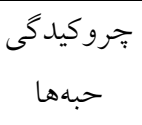 & قهوهاى شدن حبه & ريزش & \\
\hline$\wedge$ & $\wedge$ & $\wedge$ & $\wedge$ & $\wedge$ & $\wedge$ & $\wedge$ & $\wedge$ & $\wedge$ & درجه آزادى \\
\hline $0 / 49$ & $\circ / 0 \wedge$ &.$/ 1 Y$ & $\circ / 0 \Lambda$ & $0 / 01$ & $0 / 1 Y$ & $\circ / \%$ & $\circ / \mu y$ & $\circ / \circ \circ \mathrm{V}$ & .Asymp. Sig \\
\hline
\end{tabular}

جدول و. بر رسى ميزان ريزش، ظاهر و جروكيدگى حبهها بر اساس آزمون من - وينتى يو رقم "بيدانه قرمز"

\begin{tabular}{|c|c|c|c|c|}
\hline جروكيدگى حبهها & ظاهر حبهها & 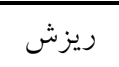 & كايتوسان (درصد) & اسانس آويشن (ميكروليتر بر ليتر) \\
\hline$r^{\mu^{a}}$ & $N / \Delta^{\text {cde }}$ & $r r^{\mu_{a}}$ & 。 & 。 \\
\hline $\mathrm{V} / 9 \mathrm{Vdd}$ & $10 / 0^{b c d}$ & $19^{\text {abcd }}$ & 。 & 100 \\
\hline$q / \Lambda \mu^{\mathrm{cd}}$ & $N / \Delta^{\text {cde }}$ & ( & $\circ$ & ro。 \\
\hline $9 / 1 V^{d}$ & $\Delta^{\mathrm{e}}$ & $11^{\mathrm{fbcd}}$ & $\circ / 0$ & $\circ$ \\
\hline$\Lambda / \Lambda \mu^{\mathrm{cd}}$ & bcde $/ \mathrm{r}$ & $\wedge^{\mathrm{d}}$ & $\circ / 0$ & 100 \\
\hline $1 r^{\text {bcd }}$ & arg & $\wedge^{\mathrm{d}}$ & $\circ / 0$ & ro。 \\
\hline$r Y / / V^{a b}$ & $\mathrm{bc}) \Lambda$ & $r l^{\mathrm{abc}}$ & 1 & $\circ$ \\
\hline $19 / \wedge \mathrm{rabcd}^{2}$ & bcde $)$ T & $\wedge^{\mathrm{d}}$ & 1 & 100 \\
\hline $19 / 0^{\mathrm{abc}}$ & $b_{Y} \circ / Q$ & $\Delta / 9 \mathrm{~V}^{\mathrm{d}}$ & 1 & ro。 \\
\hline
\end{tabular}

تيمارهايى كه داراى حداقل يك حرف مشترى هستند در سطح معنىدارى ه٪/ با هم اختلاف معنىدار ندارند.

حضور اتيلن افزايش مىيابد (Y9). دوس سـانتوس و همكـاران

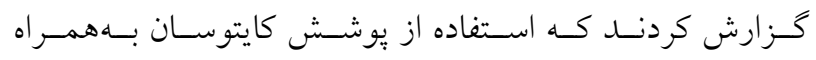
Origanum vulgare خو اص فيزيكى و فيزيكوشيميايى و نيز صـفات حسسى ميسوه را

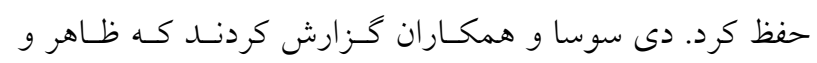
رنخ انخور رهاى يوششداده شده بـا اسـانس و شـاهد در طـول دوره نخهـــارى تفــاوت معنسى دار نشـان ندادنـــ (9). دادههـاى جدول ه نشان داد كه اثر تيمارهاى مختلف بر طعم و مـزه، بـو، بافت و نظر كلى يانليستهـا معنسىدار نبـود (جــدول ه). زو و همكاران كزارش كردند كه تيمارهاى كايتوسـان و اسـانس بـــر كريتٍ فروت، كيفيت ميوهها را بهتر حفظ مى كنند (rV). جيانـ و همكاران نيز نشان دادند كه تيمار با كايتوسان، قهـوهاى شــدن ميوهها را به تعويق انداخت (r). همجنين آنها اظهار داشتند كه كيفيت خوراكى ميوههاى ليجى تيمار شده بـا كايتوسـان يـس از

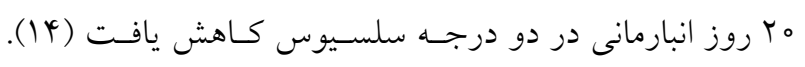

ريزش و جرو كيدكى حبهها را در مقايسه بـا شـاهد كـاهش داد.

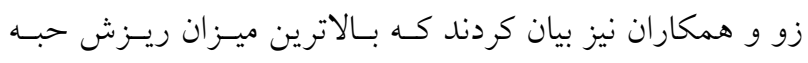
مربوط به شاهد بوده كه با وقـوع فسـاد بيشـتر در ايسن حبـههـا

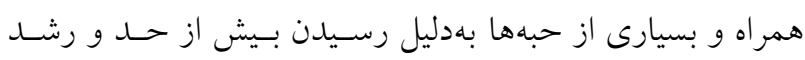
قارج سياه و نرم شده بودند (rV). كايتوسان و اسانس مانند يك يوشش روى ميوه قرار كرفته و جلوى از دسـت دادن آب ميـوه

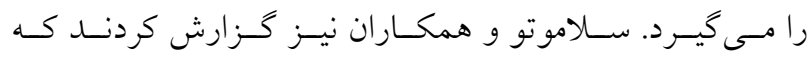
نابسامانىهاى فيزيولوزى مانند قهوهاى شدن بوسـت و گوشـت با تركيبى از اسانس تيمول و اتمسفر تغيير يافته در انخور كاهش يافت (Y9). اطلاعات نشان داد كه بوششدهى ميوهها منجـر بــه كاهش امتياز رنكى ميوهها شد كه ممكـن اسـت بـهعلـت رنـ قهـوهاى يوشـش تركيبـى (كايتوسـان + اسـانس) باشـــ. رنــ انكورهاى تمام نمونهها بهتدريج با كذشت زمـان قهـوهاى شـــ. قهوهاى شدن انكورها با فعاليت آنزيم يلىفنول اكسيداز و حمله قارجى همراه بود. كزارش شده است كه فعاليت ايسن آنـزيم در 


$$
\begin{aligned}
& \text { "جين و همكاران نيز اعـلام كردنـد، يوشـشدهـى بـا كايتوسـان معنىدارى نسبت به ساير تيمارها در بهبود كيفيت ميوههـا مـؤثر } \\
& \text { كيفيت و عمر تازه انبههاى برش يافته را افـزايش مسىدهــ (Y). بوده است. بهطوركلى، كايتوسان، اسانس و تركيب آنها توانسـت }
\end{aligned}
$$

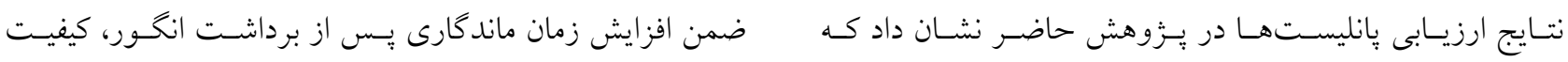

$$
\begin{aligned}
& \text { تيمارهاى مختلف تفاوت معنى دارى در طعم و مزه، بافت و نظر آنها را حفظ كند. فيلمهاى يوششى مانند سد در برابر رطوبت و } \\
& \text { كلى يانليست ها ايجاد نكردند، بنـابر اين اسـتفاده از كايتوسـان و اكسيزّن عمل كرده و نه تنها تخريب غذا را به تعويق مىاندازند، }
\end{aligned}
$$

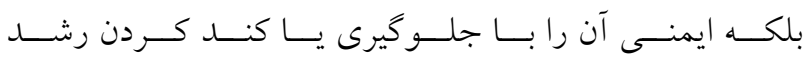

$$
\begin{aligned}
& \text { اسانس از نظر پانليستها تفاوتى با ميوههاى شاهد نداشت. } \\
& \text { ميكروار كانيسمها بهعلت فعاليت زيسـت كشىى طبيعى آنهـا يـا } \\
& \text { تلفيق تركيبات ضد ميكروبى افـزايش مسىدهنـد، همـين مســـله } \\
& \text { اجازه مىدهد كه يوششهاى خوراكى بهطسور كسترده استفاده } \\
& \text { شوند. }
\end{aligned}
$$

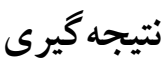

\section{منابع مورد استفاده}

1. Artes-Hernandez, F., F. A. Tomas- Bareran and F. Artes. 2006. Modified atmosphere packaging preserves quality of $\mathrm{SO}_{2}$ free Superior Seedless table grapes. Postharvest Biology and Technology 39: 146-154.

2. Azevedo, A. N., P. R. Buarque, E. M. O. Cruz, A. F. Blank, P. B. Alves, M. L. Nunes and L. C. L. A. Santan. 2014. Response surface methodology for optimisation of edible chitosan coating formulations incorporating essential oil against several foodborne pathogenic bacteria. Food Control 43: 1-9.

3. Bakkali, F., S. Averbeck, D. Averbeck and I. Idaomar. 2008. Biological effects of essential oils e a review. Food and Chemical Toxicology 46: 446-475.

4. Chien, P. J., F. Fuu Sheu and F. H. Yang. 2007. Effects of edible chitosan coating on quality and shelf life of sliced mango fruit. Journal of Food Engineering 78: 225-229.

5. Crisosto, C. H., E. J. Mitcham and A. A. Kader. 1998. Grape: recommendations for maintaining postharvest quality. http://postharvest.ucdavis.edu/PFfruits/ Grape/ (Accessed 24.11.14).

6. de Sousa, L. L., S. C. A. Andrade, A. J. A. A. Athayde, C. E. V. Oliveira, C. V. Sales, M.S . Marta Suely Madruga and E. L. Souza. 2013. Efficacy of Origanum vulgare L. and Rosmarinus officinalis L. essential oils in combination to control postharvest pathogenic Aspergilli and autochthonous mycoflora in Vitis labrusca L. (table grapes). International Journal of Food Microbiology 165: 312-318.

7. Dehestani Ardakani, M. 2008. The effect of chitosan and thymus extract on storage life and maintaining quality of two Iranian table grape, MSc. Thesis. Faculty of Agriculture Tehran University, Iran. (In Farsi).

8. dos Santos, N. S. T., A. J. A. Athayde, O. C. D. Vasconcelos de, C. V. de Sales, S. de Melo, S. R. Sousa da, S. T. C. Montenegro and E. L. De Souza. 2012. Efficacy of the application of a coating composed of chitosan and Origanum vulgare L. essential oil to control Rhizopus stolonifer and Aspergillus niger in grapes (Vitis labrusca L.). Food Microbiology 32: 345-353.

9. Ferrario-Mery, S., C. Masclaux, M. H. Aszuki, B. Valadier, K. Hirel and C. H. Foyer. 2001. Glutamine and alpha ketoglutaret are meto. Planta 213: 265-271.

10. Gao, P., Z. Zhu and P. Zhang. 2013. Effects of chitosan-glucose complex coating on postharvest quality and shelf life of table grapes. Carbohydr. Polymer 95: 371- 378.

11. Han, C., J. Zuo, Q. Xu, L. Wang, B. Zhai, Z. Wang, D. Haizhou and D. Lipu. 2014. Effects of chitosan coating on postharvest quality and shelf life of sponge gourd (Luffa cylindrica) during storage. Scientia Horticulturae 166: 1-8.

12. Hernandez-Munoz P., E. Almenar, M. J. Ocio and R. Gavara. 2006. Effect of calcium dips and chitosan coatings on postharvest life of strawberries (Fragaria $\mathrm{x}$ ananassa) Postharvest Biology and Technology 39: 247-253.

13. Jiang Y. and Y. Li. 2001. Effects of chitosan on postharvest life and quality of longan fruit. Food Chemistry 73 : 139-143.

14. Jiang, Y., J. Li and W. Jiang. 2005. Effect of chitosan coating on shelf life of cold-stored litchi fruit at ambient temperature. LWT-Food Science and Technology 38: 757-761.

15. Jobing J. 2007. Essential oils: A new idea for postharvest disease control. Sydney Postharvest Laboratory Information Sheet 11: 1-3. 
16. Kerch, G. and V. Korkhov. 2011. Effect of storage time and temperature on structure, mechanical and barrier properties of chitosan-based films. European Food Research and Technology 232(1): 17-22.

17. Kerch, G., M. Sabovics, Z. Kruma, S. Kampuse and E. Straumite. 2011. Effect of chitosan and chitooligosaccharide on vitamin $\mathrm{C}$ and polyphenols contents in cherries and strawberries during refrigerated storage. European Food Research and Technology 233(2): 351-358.

18. Krochta, J. M. 2002. Proteins as raw materials for films and coatings: definitions, current status, and opportunities. Pp: 1-41. In: A. Gennadios (Ed.), Protein-Based Films and Coatings, CRC Press, New York.

19. Liu, J., S. Tian, X. Meng and Y. Xu. 2006. Effect of chitosan on control of postharvest diseases and physiological responses of tomato fruit. Postharvest Biology and Technology 44: 300-306.

20. Martinez-Romero D., F. Guillen, J. M. Valverde, G. Bailen, P. Zapata, M. Serrano, S.Castillo and D. Valero. 2007. Influence of carvacrol on survival of Botrytis cinerea inoculated in table grapes. International Journal of Food Microbiology 115: 144-148.

21. Martínez-Romero, D., F. Guillén, J. M. Valverde, G. Bailén, P. Zapata, M. Serrano, X. Meng, B. Li, J. Liu and S. Tian. 2008. Physiological responses and quality attributes of table grape fruit to chitosan prehavest spray and postharvest coating during storage. Food Chemistry 106: 501-508.

22. Meng, X., B. Li, J. Liu and S. Tian. 2008. Physiological responses and quality attributes of table grape fruit to chitosan prehavest spray and postharvest coating during storage. Food Chemistry 106: 501-508.

23. Mostofi, Y. and F. Najafi. 2006. Laboratory Analytical Methods in Horticultural Science, Tehran University press. (In Farsi)

24. Nejad Ebrahimi, S., J. Hadian, M. H. Mirjalili, A. Sonboli and M. Yousefzadi. 2008. Essential oil composition and antibacterial activity of Thymus caramanicus at different phenological stages. Food Chemistry 110: 927-931.

25. Pedreschi, R. and S. Lurie. 2015. Advances and current challenges in understanding postharvest abiotic stresses in perishables. Postharvest Biology and Technology 107: 77-89.

26. Rinaudo, M. 2006. Chitin and chitosan: properties and applications. Progress in Polymer Science 31: $603-632$.

27. Rojas-Graü, M. A., M. S. Tapia and O. Martín-Belloso. 2008. Using polysaccharides based edible coatings to maintain quality of fresh-cut Fuji apples. LWT-e Food Science and Technology 41: 139-147.

28. Romanazzi, G., A. Lichter, F. M. Gabler and J. L. Smilanick. 2012. Recent advances on the use of natural and safe alternatives to conventional methods to control postharvest gray mold of table grapes. Postharvest Biology and Technology 63: 141-147.

29. Sellamuthu, P. S., D. Sivakumar, P. Soundy and L. Korsten. 2013. Enhancing the defense related and antioxidant enzymes activities in avocado cultivars with essential oil vapors. Postharvest Biology and Technology 81: 66-72.

30. Serrano, M., D. Martinez-Romero, F. Guillen, J. M. Valverde, P. J. Zapata, S. Castillo and D. Valero. 2008. The addition of essential oils to MAP as a tool to maintain the overall quality of fruits. Trends in Food Science and Technology 9: 464-471.

31. Simoes, A. D. N., J. A. Tudela, A. Allende, R. Puschmann and M. I. Gil. 2013. Edible coatings containing chitosan and moderate modified atmospheres maintain quality and enhance phytochemicals of carrot sticks. Postharvest Biology and Technology 51: 364-370.

32. Sousa, J. P., G. A. Azêredo, M. A. S. Vasconcelos, R. A. Torres, M. L. Conceiçao and E. L. Da Souza. 2012. Synergies of carvacrol and 1,8-cineole to inhibit bacteria associated with minimally processed vegetables. International Journal of Food Microbiology 154: 145-151.

33. Sun, X., J. Narciso, Z. Wang, C. Ference, J. Bai and K. Zhou. 2014. Effects of chitosan-essential oil coatings on safety and quality of fresh blueberries. Journal of Food Science 79: M955-M960.

34. Thumula, P. 2006. Studies on storage behaviour of tomatoes coated with chitosan-lysozyme films. MSc. Thesis. Department of Bioresource Engineering Faculty of Agricultural and Environmental Sciences. McGill University Montreal, Quebec, Canada.

35. Valero, D., J. M. valverde, D. M. Romero, F. Guillen, S. Castillo and M. Serrano. 2006. The combination of modified atmosphere packaging with eugenol or thymol maintain quality, safety and functional properties of table grapes. Postharvest Biology and Technology 41: 317-327.

36. Wang, S. Y. and H. Gao. 2013. Effect of chitosan-based edible coating on antioxidants, antioxidant enzyme system, and postharvest fruit quality of strawberries (Fragaria $x$ aranassa Duch.). LWT-Food Science and Technology 52: 71-79.

37. Xu, W. T., K. L. Huang, F. Guo, W. Qu, J. J. Yang, Z. H. Liang and Y. B. Luo. 2007. Postharvest grapefruit seed extract and chitosan treatments of table grapes to control Botrytis cinerea. Postharvest Biology and Technology 46: 86-94.

38.Youwei, Y. and R. Yinzhe. 2013. Effect of chitosan coating on preserving character of post-harvest fruit and vegetable: A Review. Journal of Food Process Technology 4: 8-18. 


\title{
Maintaining Quality Properties of Grape CV. 'Bidaneh Ghermez' by Chitosan Edible Coating, Thymus Essential Oil and their Concomitant Application
}

\author{
M. Dehestani ${ }^{1^{*}}$ and Y. Mostofi ${ }^{2}$ \\ (Received: January 25-2017; Accepted: February 10-2019)
}

\begin{abstract}
The application of edible coatings is one of the most innovative methods to extend the commercial shelf-life of fruits and vegetables by acting as a gas barrier. In this study, the effects of chitosan, thymus essential oil and their combination in extending shelf life of grape ('Bidaneh Ghermez') and quality properties were investigated. Grapes were harvested when were fully ripened and their total soluble solid (TSS) was about $25 \%$ and immediately transferred to laboratory. Then fruit treated by $0.5 \%$ and $1 \%(\mathrm{w} / \mathrm{v})$ solution of chitosan, 150 and $300 \mu \mathrm{l} / 1$ thymus essential oil and their combination (untreated fruit were as control). After treatments, grapes were packed in $200 \mathrm{~g}$ packages and stored at $0-2$ ${ }^{\circ} \mathrm{C}$ and $90 \% \pm 5 \mathrm{RH}$ for 60 days. Changes in weight loss, color, $\mathrm{pH}$, TSS, decay and sensory quality were measured in ten-day intervals until 60 days after the treatments. Results showed that chitosan and essential oil treatment significantly decreased weight loss, decay, color change, shrivel and berry shatter in comparison to the control. According to the panelists' votes, treated fruits did not show significant difference to the non-treated control fruits. It seems that among different treatments examined, the combined treatment of chitosan and thymus essential oil was more suitable for maintaining the fruit quality.
\end{abstract}

Keywords: Table grape, Postharvest life, Fungal decay, Quality

1. Assistant Professor, Department of Horticultural Science, College of Agriculture and Natural Resources, Ardakan University, Ardakan, Iran.

2. Professor, Department of Horticultural Science and Landscape Architecture, Faculty of Agricultural Science and Engineering, College of Agriculture and Natural Resources, University of Tehran, Karaj, Iran.

*: Corresponding Author, Email: mdehestani@ardakan.ac.ir 